\title{
Comparative Proximate and Mineral Composition of Moringa oleifera and Moringa ovalifolia Grown in Central Namibia
}

\author{
Morlu Korsor ${ }^{1}$, Charles Ntahonshikira ${ }^{2}$, Haruna M. Bello ${ }^{3}$ \& Habauka M. Kwaambwa ${ }^{4}$ \\ ${ }^{1}$ University of Namibia, Department of Animal Science, Windhoek, Namibia \\ ${ }^{2}$ University of Namibia, School of Veterinary Medicine, Windhoek, Namibia \\ ${ }^{3}$ University of Namibia, Department of Agricultural Economics, Windhoek, Namibia \\ ${ }^{4}$ Namibia University of Science and Technology, Department of Natural and Applied Sciences, Windhoek, \\ Namibia \\ Correspondence: Charles Ntahonshikira, University of Namibia, School of Veterinary Medicine, Private Bag \\ 13188, Windhoek, Namibia. Tel: 264-612-016-3815. E-mail: cntahonshikira@unam.na
}

Received: May 11, 2017 Accepted: June 25, 2017 Online Published: August 3, 2017

doi:10.5539/sar.v6n4p31 URL: https://doi.org/10.5539/sar.v6n4p31

\begin{abstract}
The objective of this study was to compare the proximate and mineral compositions of Moringa oleifera and Moringa ovalifolia grown together at Neudamm Experimental Farm in central Namibia. Moringa oleifera is well known for its rich nutritional value and was compared to the nutritional value of $M$. ovalifolia, a native plant of Namibia and Angola, which is less studied. Namibia being a semi-arid country, many plants in the rangelands are low in nutrients essential for livestock nutrition. This creates the necessity for planting fodder trees like moringa that withstand the harsh climatic conditions and retain their nutritional quality for the production of sustained livestock supplement. Leaves of both Moringa species were harvested with twiglets, shade dried fortnightly and taken to the laboratory where they were ground and passed through $1 \mathrm{~mm}$ sieve for proximate and mineral analysis. Statistically, M. oleifera nutrient values were significantly different $(\mathrm{P}<0.05)$ in moisture, ash, crude protein $(\mathrm{CP})$ and crude fiber (CF) from M. ovalifolia, but had no differences in fat, acid detergent fiber (ADF) and neutral detergent fiber (NDF). Also, M. oleifera was significantly different $(\mathrm{P}<0.05)$ from $M$. ovalifolia in potassium $(\mathrm{K})$, magnesium $(\mathrm{Mg})$, copper $(\mathrm{Cu})$ and zinc $(\mathrm{Zn})$, but there were no differences in calcium $(\mathrm{Ca})$, sodium $(\mathrm{Na})$, phosphorus $(\mathrm{P})$, iron $(\mathrm{Fe})$ and manganese $(\mathrm{Mn})$ values. This implies that both Moringa species have similar quantity of $\mathrm{Ca}, \mathrm{Na}, \mathrm{P}, \mathrm{Fe}$ and $\mathrm{Mn}$ in their leaf tissues. The almost identical nutrient values of the two Moringa species, suggests that $M$. ovalifolia could serve as an alternative supplement for livestock since there is a known human-livestock competition for M. oleifera, and since M. ovalifolia is native and well adapted to the harsh environmental conditions of Namibia.
\end{abstract}

Keywords: Central Namibia, mineral composition, Moringa oleifera, Moringa ovalifolia, proximate composition

\section{Introduction}

The 13 species of Moringa trees belonging to the family Moringaceae are divided into 3 major groups based on the shapes of their trunks: slender trees, bottle trees and tuberous shrubs. Among the Moringa species, Moringa oleifera (M. oleifera) seems to have been the most adapted plant worldwide, compared to other species. It is also the most widely known. Many studies have been done on its uses and numerous beneficial properties in the plant kingdom (Fuglie, 2001; Olson, 2001; Prince, 2007; Hiawacha Bey, 2010).

Moringa oleifera tree is native to the southern foothills of Himalayans in northern India, but it has been planted around the world and has naturalized in many countries. It has a high growth rate and capacity to produce large quantities of fresh biomass (Fuglie, 2001; Sanchez, Ledin, \& Ledin, 2006; Price, 2007). It is commonly known as a horse-radish or drumstick tree in English and used as traditional medicine and livestock feed in many tropical and subtropical countries. Advantageously, it is a rapidly growing drought-resistant-deciduous tree even in poor soils ( Fuglie, 2001; Alhakman, Kumar, \& Khan, 2013).

Moringa ovalifolia (M. ovalifolia), which is described as a bottle tree because of its trunk, is a native tree to Namibia and Angola. This species is generally uncommon, but widespread in western Namibia, as far south as 
$26^{\circ} \mathrm{S}$; scattered localities in the Karstveld and occasional in the south, while it is common in the central areas. It grows in the wild in both countries. It is a small deciduous tree with a distinctive, squat, swollen stem and branches and is commonly known as "ghost tree or phantom tree". The roots, bark and wood are eaten by goats; trees are also browsed by giraffe (Olson, 2001; Curtis and Mannheimer, 2005; Wyk, Wyk, and Wyk, 2011). Although many studies have shown that M. oleifera is readily eaten by animals as a fodder, little is known about M. ovalifolia even though it is also proven to be eaten by animals ( Foidl, Makkar, \& Becker, 2001; Wyk et al., 2011; Alhakman et al., 2013).

Good fodder species contain high levels of protein and some important minerals like phosphorus $(\mathrm{P})$ which make animals grow rapidly (Pace Project, n.d.). The production of additional fodder from dry-land, cultivated grass pastures and plantations of drought-tolerant fodder shrubs should become a priority in dry, mostly desert countries like Namibia so that livestock production could no longer be dependent solely on highly sensitive native rangeland but also include other sources of fodder (Sijssens, 2014). Nutritional and medicinal properties of $M$. oleifera have the potential to alleviate malnutrition, starvation, as well as prevent and heal many diseases and maladies (Hiawacha Bey, 2010). The leaves are highly nutritious, and also considered as a source of beta-carotene, vitamin C, protein, iron and potassium (Makkar and Becker, 2007). Phytochemical analysis of $M$. oleifera have shown that its leaves are particularly rich in potassium, calcium, phosphorous, iron, vitamins A and $\mathrm{D}$ as well as in essential amino acids (Mbikay, 2012). Research shows that every $100 \mathrm{~g}$ of M. oleifera of leaf powder contain $27.1 \mathrm{~g}$ of protein, $259 \mathrm{mg}$ of mineral potassium $(\mathrm{K}), 6.8 \mathrm{mg}$ of vitamin A - -carotene, while the pods contain $2.5 \mathrm{~g}$ of protein, $259 \mathrm{mg} \mathrm{K}$ in pods (Prince, 2007). In a study by Sanchez-Machado, Núñez-Gastélum, Reyes-Moreno, Ramírez-Wong, \& López-Cervantes (2010), chemical composition (of dry leaves) ranged from $19.34 \%$ to $22.42 \%$ for protein, $1.28 \%$ to $4.96 \%$ for lipids, $7.62 \%$ to $14.60 \%$ for ash, and $30.97 \%$ to $46.78 \%$ for dietary fiber. They concluded that the leaves and flowers are a protein source with an adequate profile of amino acids and ash, while the immature pods show a high content of dietary fiber and low lipid content. The crude protein content of extracted and unextracted moringa leaves was 43.5 and $25.1 \%$, respectively, suggesting that both the extracted and unextracted leaves are good sources of protein for livestock (Foidl, Makkar, \& Becker, 2001).

Moringa oleifera leaves have a high potential as a protein source supplement for ruminants and their nutritional value is similar to that of the widely used soybean meal and rapeseed meal (Soliva, Kreuzer, Foidl, Machmuller, \& Hess, 2005). It has proven to be a valuable supplement for animals in other countries (Mendieta, Reyes, \& Rodriquez, 2007; Ojukwu, 2012). This means that feeding it at the appropriate period of nutritional needs especially during pregnancy for proper foetus development and during lactation for early growth and development of the new born animal is essential.

Moringa can be used as a food for human consumption in addition to being used as feed or fodder for animals. It can be prepared in different forms for human consumption and eaten either raw or dry by animals. In the tropics, it is used as a forage for livestock and in many countries as vegetables that have the potential to improve nutrition, ensure food security, foster rural development and support sustainable land care (Foidl et al., 2011; Joshua and Vasu, 2013). However, whether used as food or feed for livestock, the benefits of moringa have become increasingly obvious and demand concerted national action (Ojukwu, 2012). It is upon this background that this study was undertaken to compare the chemical and nutritional composition of M. oleifera, which has been widely researched, with that of M. ovalifolia that has scantily been researched and reported in literature.

\section{Materials and Methods}

\subsection{Study Area}

A moringa orchard of 0.21 hectares ( 0.11 hectares for M. oleifera and 0.10 hectares for M. ovalifolia) was established in 2014 at the Neudamm Experimental Farm of the University of Namibia, about $30 \mathrm{~km}$ east of Windhoek. The Experimental Farm has a total area of about 10,187 hectares. Neudamm Campus is located at $22^{\circ}$ $30^{\prime} 07^{\prime \prime} \mathrm{S}$ and at $17^{\circ} 22^{\prime} 14^{\prime \prime} \mathrm{E}$, and at an altitude of 1762 meters above sea level. The farm's temperature ranges between a minimum of $-7^{\circ} \mathrm{C}$ in winter and a maximum of $44^{\circ} \mathrm{C}$ in summer (University of Namibia, 2011), and received annual average rainfall of $229 \mathrm{~mm}$ and $247.8 \mathrm{~mm}$ in 2014/2015 and 2015/2016 summer seasons respectively (Beukes, 2017).

\subsection{Sample Collection}

Thirty-day-old Moringa oleifera and $M$ ovalifolia leaves with their twiglets were randomly collected from the Moringa orchard. Leaves were randomly harvested from each block for both Moringa species to compare the chemical and nutritional composition between species as well as among blocks. Data was collected during 2014/2015 and 2015/2016 summer seasons after the trees were well established and had leaves. In Namibia, 
summer extends from September to April of the following year when rainfall is more than 99\% (Pallett, 1994) and temperatures are optimal for plant growth.

\subsection{Sample Preparation}

Moringa leaves were dried in the shade for two weeks as described by Madukwe, Ezeugwu and Eme (2013) and taken to the nutrition laboratory of the Ministry of Agriculture, Water and Forestry in Windhoek where subsequent preparation and analysis were done. Leaf samples from both Moringa species were ground to powder and allowed to pass through a sieve with circular openings of $1 \mathrm{~mm}$ diameter and stored in clean and labelled plastic bottles until analysis (AgriLASA, 1993; AOAC, 2006).

\subsection{Nutritional Analysis Procedures}

Moringa oleifera and M. ovalifolia leaf samples were analysed for nutritional composition such as moisture, ash, fat, crude fibre (CF), crude protein (CP), acid detergent fibre (ADF), neutral detergent fibre (NDF), carbohydrate, total digestible nutrients (TDN), digestible energy (DE), metabolisable energy (ME), calcium (Ca), phosphorus $(\mathrm{P})$, sodium $(\mathrm{Na})$, potassium $(\mathrm{K})$, magnesium $(\mathrm{Mg})$, manganese $(\mathrm{Mn})$, iron $(\mathrm{Fe})$, zinc $(\mathrm{Zn})$, copper $(\mathrm{Cu})$ and water soluble tannins using the procedures of the Association of the Official Agricultural Chemists (AgriLASA, 1993; AOAC, 2006; Cunniff, 1996).

Protein content was determined using a combustion method in a CHN628 machine. Approximately $0.1 \mathrm{~g}$ of a sample was weighed into a foil cup and placed in a CHN628 Leco Machine. Samples were burned at $950^{\circ} \mathrm{C}$ in the presence of oxygen, and then the released gases were separated by helium. The released nitrogen was measured in a thermal conductivity cell and the results were automatically captured and the readings were seen on the screen. The protein percentage was calculated by multiplying the reported nitrogen by 6.25 . Disodium ethylenediaminetetraacetate (EDTA) was used for quality control during analysis (AgriLASA, 1993; AOAC, 2006).

Crude fiber was determined using Weende method (AgriLASA, 1993), in which a FIWE Raw Fiber Extractor was used. A ground sample of approximately $1 \mathrm{~g}$ was weighed in glass crucibles, inserted into the extractor to which $150 \mathrm{~mL}$ of diluted and preheated sulfuric acid $\left(\mathrm{H}_{2} \mathrm{SO}_{4}\right)$ was added, followed by 4 drops of antifoam agent (n-octanol) and boiled for 30 minutes. Afterwards, filtering of the remaining reagent was done and washed 3 times with de-ionized hot water. Thereafter, $150 \mathrm{~mL}$ of sodium hydroxide was added followed by 4 drops of $\mathrm{n}$-octanol and the mixture was boiled for another 30 minutes. Then, the reagent was filtered out and washed 3 times with de-ionized hot water. The remaining residues were dried at $105^{\circ} \mathrm{C}$ for five hours in a conventional oven, cooled in a desiccator and weighed to obtain the crude fiber contents. The percentage crude fiber was calculated as follows:

$$
\text { Crude Fiber }(\%)=\frac{(\mathrm{F} 1-\mathrm{F} 2)}{\mathrm{F} 0} \times 100
$$

where F0, F1 and F2 represent the weights of sample, crude fiber plus ash content and ash, respectively. Ash content was determined by placing dried residues from crude fiber in a muffle furnace at a temperature of $550^{\circ} \mathrm{C}$ for 5 hours, cooled in a desiccator and weighed to obtain the ash (AgriLASA, 1993; AOAC, 2006).

Acid detergent fiber (ADF) was determined using Weende method (AgriLASA, 1993), in which a FIWE Raw Fiber Extractor was used. A ground sample of approximately $1 \mathrm{~g}$ was weighed in glass crucible, inserted into the extractor to which $100 \mathrm{~mL}$ of cetyltrimethylammonium bromide technical grade $\left(\mathrm{C}_{19} \mathrm{H}_{42} \mathrm{BrN}\right)$ and sulfuric acid $\left(\mathrm{H}_{2} \mathrm{SO}_{4}\right)$ with 4 drops of n-octanol were added and then left to boil for one hour. Afterwards, filtering of the remaining reagent was done and it was washed 3 times with de-ionized hot water. The remaining residues were dried at $105^{\circ} \mathrm{C}$ to constant weight in a conventional oven, cooled in a desiccator and weighed to obtain the acid detergent fibers. The ADF was calculated using the formula:

$$
\mathrm{ADF} \%=\frac{\mathrm{w}_{\mathrm{r}}}{\mathrm{w}_{\mathrm{s}}} \mathrm{x} 100
$$

where $\mathrm{W}_{\mathrm{r}}$ is the weight of the residue after heating and $\mathrm{W}_{\mathrm{s}}$ is the weight of the sample (AgriLASA, 1993; AOAC, 2006).

Neutral detergent fiber (NDF) was also determined using Weende method (AgriLASA, 1993) in which a FIWE Raw Fiber Extractor was used. A ground sample of approximately $1 \mathrm{~g}$ was weighed in glass crucible, inserted into the extractor machine, then $100 \mathrm{~mL}$ of sodium borate decahydrate $\left(\mathrm{Na}_{2} \mathrm{~B}_{4} \mathrm{O}_{7 \cdot 10} \mathrm{H}_{2} \mathrm{O}\right)$, disodium ethylenediaminetetraacetate (EDTA, $\mathrm{C}_{10} \mathrm{H}_{14} \mathrm{Na}_{2} \mathrm{O}_{8}$ ), sodium lauryl sulfate neutral $\left(\mathrm{C}_{12} \mathrm{H}_{25} \mathrm{NaO}_{4} \mathrm{~S}\right.$ ), 
2-ethoxyethanol (Ethylene glycol monoethyl ether, cellosolve, $\mathrm{C}_{4} \mathrm{H}_{10} \mathrm{O}_{2}$ ), and disodium phosphate anhydrous $\left(\mathrm{Na}_{2} \mathrm{HPO}_{4}\right)$ with 4 drops of $\mathrm{n}$-octanol (antifoam agent) added. The mixture was allowed to boil for one hour and the boiled mixture was filtered and then washed 3 times with de-ionized hot water. Afterwards, the washed residue was dried at $105^{\circ} \mathrm{C}$ to constant weight in a conventional oven, cooled in a desiccator and weighed to obtain the neutral detergent fiber. The NDF was calculated using the equation (2) as for ADF.

The moisture from a sample is driven off by the use of heat, and the weight loss is used to calculate the moisture content (AgriLASA, 1993). The moisture content was determined by heating the samples in a vacuum oven at a temperature of $105^{\circ} \mathrm{C}$ to constant weight and cooled in a desiccator as described by Sanchez et al. (2006). Then the weights lost from the heated samples were used to calculate the moisture content as

$$
\text { Moisture (\%) }=\frac{\mathrm{W}_{2}-\mathrm{W}_{3}}{\mathrm{~W}_{2}-\mathrm{W}_{1}} \times 100
$$

where $\mathrm{W}_{1}$ is the dish (without lid) weight, $\mathrm{W}_{2}$ is the sample plus dish and $\mathrm{W}_{3}$ is the sample plus dish after drying (AgriLASA, 1993).

Fat content was determined using the Solvent Extractor Machine (VELP SICIENTIFICA). About $3 \mathrm{~g}$ of sample was weighed in the extraction thimbles and hooked in the Solvent Extractor Machine. Beakers were weighed with boiling stone in each of them and $60 \mathrm{~mL}$ of petroleum ether was added and then was put in the extractor machine in which the extraction thimbles were submerged. The tap was open for condensation and the machine knot was moved to level one (immersion) and boiled at $110^{\circ} \mathrm{C}$ temperature for an hour, then the knot was moved to level two (washing) for another hour boiling and finally the knot was moved to level three (recover) for the last one hour boiling. The boiling stone was used to create a calm boiling process. After boiling, the beakers with recovered samples were placed in a conventional oven at $105^{\circ} \mathrm{C}$ temperature to dry for 30 minutes. Subsequently, beakers were removed and placed in a desiccator, cooled, weighed and the fat content was calculated as

$$
\text { Crude fat }(\%)=\underline{\text { MFR }- \text { MF }} \times 100
$$

$\mathrm{m}$

where $\mathrm{m}, \mathrm{MF}$ and MFR represent mass of sample used, mass of flask, and mass of flask with extracted reside, all in grams, respectively (AgriLASA, 1993; AOAC, 2006).

Mineral analysis was determined by the Atomic Emission Spectroscopy (AES) method using Inductively Coupled Plasma (ICP) instrument. The elements $\mathrm{Ca}, \mathrm{P}, \mathrm{Na}, \mathrm{K}, \mathrm{Mg}, \mathrm{Mn}, \mathrm{Fe}, \mathrm{Zn}$ and $\mathrm{Cu}$ were analysed. This analytical method allows the isolation of minerals from organic matter prior to the analysis by first ashing samples. The ashed samples were digested consecutively by hydrochloric and nitric acids to decompose them. The digested samples were filtered before being diluted with de-ionized water. The sample diluents were injected into ICP-MS instrument for analysis and gave the concentration of individual minerals.

Water soluble tannins were determined using in house method of aqueous extraction followed by colorimetric determination (Folin and Ciocalteu's phenol regent). Non-structural carbohydrates were determined using calculated differences. Total digestible nutrients, digestible energy and metabolisable energy were also determined by calculation (AOAC, 2006; Galyean, 2010).

\subsection{Data Analysis}

One-sample t-test analysis was used for M. oleifera and M. ovalifolia nutrient composition data analysis in which the means of M. oleifera were compared with the means of M. ovalifolia using Statistical Package for Social Sciences $\left(\right.$ SPSS $^{\circledR}$ version 23). Means of blocks were derived using Microsoft Office Excel ${ }^{\circledR}$ program that compared the nutrient composition of M. oleifera and M. ovalifolia.

\section{Results}

The results of this study include the proximate and mineral compositions of M. oleifera and M. ovalifolia leaves. The results for moisture, ash, fat, $\mathrm{CP}, \mathrm{CF}, \mathrm{ADF}, \mathrm{NDF}, \mathrm{Ca}, \mathrm{P}, \mathrm{K}, \mathrm{Na}, \mathrm{Mg}$ were presented in percent dry weight (\% $\mathrm{DW}$ ) because they found in large quantities, while $\mathrm{Cu}, \mathrm{Fe}, \mathrm{Mn}$ and $\mathrm{Zn}$ are reported in parts per million (ppm) since they are found in small quantities as suggested by Hochmuth, Maynard, Vavrina, Hanlon, and Simonne (2015). Total digestible nutrients are expressed in g/100 g, both digestible energy and metabolisable energy in $\mathrm{MJ} / \mathrm{kg}$, while water soluble tannins are in $\mathrm{g} / 100 \mathrm{~g}$. All analytical results in the tables are presented 'as is'.

\subsection{Nutrient Compositions of M. oleifera and M. ovalifolia}

Table 1 shows the proximate and mineral composition of M. oleifera and M. ovalifolia leaves using M. ovalifolia means as test values against $M$. oleifera in a one-sample t-test analysis. Moisture content, fat, $\mathrm{CP}, \mathrm{CF}, \mathrm{ADF}$ and 
NDF parameters were used as proximate composition while $\mathrm{Ca}, \mathrm{P}, \mathrm{F}, \mathrm{Mg}, \mathrm{Na}$ were used as macro-nutrients; $\mathrm{Cu}$, $\mathrm{Fe}, \mathrm{Mn}$ and $\mathrm{Zn}$ were used as micro-nutrients. Statistically, M. oleifera proximate nutrient values were significantly different $(\mathrm{P}<0.05)$ in moisture, ash, $\mathrm{CP}$ and $\mathrm{CF}$ from $M$. ovalifolia, but there were no significant differences $(\mathrm{P}>0.05)$ in fat, $\mathrm{ADF}$ and NDF. This means that fat, ADF and NDF nutrient values are similar in both Moringa species. For mineral composition, M. oleifera was significantly different $(\mathrm{P}<0.05)$ from $M$. ovalifolia in $\mathrm{K}, \mathrm{Mg}, \mathrm{Cu}$ and $\mathrm{Zn}$ content; but, there were no differences in $\mathrm{Ca}, \mathrm{Na}, \mathrm{P}, \mathrm{Fe}$ and $\mathrm{Mn}$ values. This implies that both Moringa species have similar content of $\mathrm{Ca}, \mathrm{Na}, \mathrm{P}, \mathrm{Fe}$ and $\mathrm{Mn}$ in their leaf tissues. The differences in mineral nutrient values can be attributed to the higher ash content of $M$. ovalifolia as compared to M. oleifera because, it is an approximation of the total mineral (inorganic) portion of the feed sample as defined by (Tisch, 2006). Table 2 indicates the level of TDN, DE, ME and tannins contents in M. oleifera and M. ovalifolia leaves in which the total mean and standard error of the mean (SEM) were considered.

Table 1. Comparison of M. oleifera and M. ovalifolia leaves proximate and mineral composition ( $\mathrm{g} / 100 \mathrm{~g})$

\begin{tabular}{|c|c|c|c|c|c|c|}
\hline \multirow{2}{*}{$\begin{array}{l}\text { Nutrient } \\
\text { (\% in DW) }\end{array}$} & \multicolumn{2}{|c|}{ Mean } & \multirow{2}{*}{$\begin{array}{c}\text { Std. } \\
\text { Deviation }\end{array}$} & \multirow{2}{*}{$\begin{array}{c}\text { Std. Error } \\
\text { Mean }\end{array}$} & \multirow[t]{2}{*}{$\mathrm{t}$} & \multirow[b]{2}{*}{ P-values } \\
\hline & M. ovalifolia & M. oleifera & & & & \\
\hline Moisture & 6.2 & 6.025 & 0.191 & 0.068 & -2.588 & 0.036 \\
\hline Ash & 11.32 & 10.653 & 0.391 & 0.138 & -4.822 & 0.002 \\
\hline Fat & 5.795 & 6.608 & 1.569 & 0.555 & 1.465 & 0.186 \\
\hline $\mathrm{CP}$ & 28.68 & 30.988 & 0.908 & 0.321 & 7.189 & 0.000 \\
\hline $\mathrm{CF}$ & 8.458 & 8.115 & 0.410 & 0.145 & -2.366 & 0.050 \\
\hline $\mathrm{ADF}$ & 11.78 & 10.961 & 1.469 & 0.519 & -1.576 & 0.159 \\
\hline NDF & 13.92 & 12.835 & 3.047 & 1.077 & -1.007 & 0.347 \\
\hline \multicolumn{7}{|c|}{ Macro-nutrients (\% in DW) } \\
\hline $\mathrm{Ca}$ & 1.711 & 1.206 & 0.857 & 0.303 & -1.667 & 0.139 \\
\hline $\mathrm{P}$ & 0.368 & 0.265 & 0.195 & 0.069 & -1.502 & 0.177 \\
\hline $\mathrm{K}$ & 0.796 & 0.578 & 0.309 & 0.109 & -1.992 & 0.087 \\
\hline $\mathrm{Mg}$ & 0.182 & 0.074 & 0.045 & 0.016 & -6.787 & 0.000 \\
\hline $\mathrm{Na}$ & 0.224 & 0.656 & 1.372 & 0.485 & 0.891 & 0.402 \\
\hline \multicolumn{7}{|c|}{ Macro-nutrients (ppm) } \\
\hline $\mathrm{Cu}$ & 13.1 & 15.093 & 1.965 & 0.694 & 2.870 & 0.024 \\
\hline $\mathrm{Fe}$ & 174.7 & 177.105 & 11.168 & 3.948 & 0.609 & 0.562 \\
\hline $\mathrm{Mn}$ & 0.001 & 0.358 & 0.857 & 0.357 & 1.000 & 0.351 \\
\hline $\mathrm{Zn}$ & 13.51 & 20.499 & 0.195 & 0.746 & 9.373 & 0.000 \\
\hline
\end{tabular}

Results are presented 'as is'.

Table 2. Total digestible nutrients, digestible energy, metabolisable energy and Tannins contents in $M$. oleifera and M. ovalifolia

\begin{tabular}{lcccc}
\hline Nutrients $(\mathrm{g} / 100 \mathrm{~g})$ & M. oleifera & M. ovalifolia & Total Mean & SEM \\
Total digestible nutrients & 67 & 62 & 64.5 & 4.419 \\
Digestible energy & 12 & 12 & 12 & 0.000 \\
Metabolisable energy & 11 & 10 & 10.5 & 0.177 \\
Tannins (tannic acid) & 3.9 & 4.4 & 4.15 & 0.044 \\
\hline
\end{tabular}

Results are presented 'as is'.

\subsection{Comparison of M. oleifera Nutritional Compositions within Blocks}

Table 3 shows the proximate and mineral composition of M. oleifera leaves in which blocks B2, B3 and B4 means were compared with the control block (B1) mean. Moringa oleifera seedlings were transplanted in four blocks with four treatment levels: B1 (0 g), block2 (100 g), block3 (200 g) and block4 (300 g) of superphosphate fertilizer with a P content of $83 \mathrm{~g} / \mathrm{kg}$ (Wonder superphosphate granular, AGRO-SERVE (Pty) Ltd., Bryanston, South Africa and nitrogen fertilizer with an N content of $280 \mathrm{~g} / \mathrm{kg}$ (Limestone Ammonium Nitrate - LAN), WONDER HORTICULTURAL PRODUCTS (Pty) Ltd., Silverton, South Africa for roots and leaves development. The one sample t-test analysis result revealed no significant differences $(\mathrm{P}>0.05)$ within blocks in moisture content, ash, fat, $\mathrm{CP}, \mathrm{CF}$ and $\mathrm{ADF}$, except NDF that was statistically different $(\mathrm{P}<0.05)$ between control and other blocks, which might be attributed to M. oleifera's high level of NDF without fertilizers. Also, there were no significant differences $(\mathrm{P}>0.05)$ in $\mathrm{Ca}, \mathrm{K}, \mathrm{Mg}, \mathrm{P}, \mathrm{Cu}$ and $\mathrm{Mn}$ content between the control block 
and other blocks, except for $\mathrm{Na}, \mathrm{Fe}$ and $\mathrm{Zn}$ which were significantly different $(\mathrm{P}<0.05)$ in mineral values.

Table 3. Comparison of proximate and mineral composition of M. oleifera leaves in different treatments $(\mathrm{g} / 100 \mathrm{~g})$

\begin{tabular}{|c|c|c|c|c|c|c|}
\hline \multirow{2}{*}{$\begin{array}{l}\text { Nutrients } \\
(\% \text { in DW) }\end{array}$} & \multicolumn{2}{|c|}{ Mean } & \multirow{2}{*}{$\begin{array}{c}\text { Std. } \\
\text { Deviation }\end{array}$} & \multirow{2}{*}{$\begin{array}{c}\text { Std. Error } \\
\text { Mean }\end{array}$} & \multirow[b]{2}{*}{$\mathrm{t}$} & \multirow[b]{2}{*}{ P-values } \\
\hline & Control block & Fertilized blocks & & & & \\
\hline Moisture & 5.975 & 6.042 & 0.227 & 0.131 & 0.509 & 0.661 \\
\hline Ash & 10.775 & 10.612 & 0.439 & 0.253 & -0.644 & 0.585 \\
\hline Fat & 5.695 & 6.912 & 1.303 & 0.752 & 1.617 & 0.247 \\
\hline $\mathrm{CP}$ & 30.95 & 31.000 & 0.265 & 0.153 & 0.327 & 0.775 \\
\hline $\mathrm{CF}$ & 8.15 & 8.103 & 0.215 & 0.124 & -0.377 & 0.743 \\
\hline $\mathrm{ADF}$ & 10.055 & 11.263 & 1.656 & 0.956 & 1.264 & 0.334 \\
\hline NDF & 15.725 & 11.872 & 1.340 & 0.774 & -4.980 & 0.038 \\
\hline \multicolumn{7}{|c|}{ Macro-nutrients (\% in DW) } \\
\hline $\mathrm{Ca}$ & 1.419 & 1.135 & 0.404 & 0.233 & -1.219 & 0.347 \\
\hline $\mathrm{P}$ & 0.2865 & 0.257 & 0.153 & 0.088 & 0.069 & 0.951 \\
\hline $\mathrm{K}$ & 0.5705 & 0.581 & 0.254 & 0.147 & 0.857 & 0.482 \\
\hline $\mathrm{Mg}$ & 0.0615 & 0.078 & 0.033 & 0.019 & -35.371 & 0.001 \\
\hline $\mathrm{Na}$ & 2.1125 & 0.171 & 0.095 & 0.055 & -0.330 & 0.773 \\
\hline \multicolumn{7}{|c|}{ Micro-nutrients (ppm) } \\
\hline $\mathrm{Cu}$ & 14.585 & 15.263 & 1.469 & 0.848 & 0.799 & 0.508 \\
\hline $\mathrm{Fe}$ & 181.722 & 175.566 & 3.523 & 2.034 & -3.026 & 0.094 \\
\hline $\mathrm{Mn}$ & 0.001 & 0.477 & 0.825 & 0.476 & 1.000 & 0.423 \\
\hline $\mathrm{Zn}$ & 18.957 & 21.013 & 1.207 & 0.697 & -1.219 & 0.098 \\
\hline
\end{tabular}

Results are presented 'as is'.

Table 4 shows the comparison of proximate and mineral compositions of M. oleifera blocks (B1, B2, B3 and B4) in which B1 served as a negative control (i.e. without fertilizer). The results for proximate composition show that $\mathrm{CP}$ was the highest followed by NDF, ADF and ash while the moisture, fat and CF nutrient values were < $9 \%$ in all blocks. The results revealed that $\mathrm{Fe}$ had the highest values among the minerals followed by $\mathrm{Zn}$ and $\mathrm{Cu}$ while $\mathrm{Ca}, \mathrm{K}, \mathrm{Mg}, \mathrm{Na}, \mathrm{P}$ and $\mathrm{Mn}$ were $<3 \%$ in values for all blocks.

Table 4. Comparison of proximate and mineral compositions of M. oleifera leaves $(\mathrm{g} / 100 \mathrm{~g})$ within blocks

\begin{tabular}{lcccc}
\hline Nutrients (\% in DW) & Block 1 & Block 2 & Block 3 & Block 4 \\
\hline Moisture & 5.975 & 6.185 & 5.78 & 6.16 \\
Ash & 10.775 & 11.07 & 10.195 & 10.57 \\
Fat & 5.695 & 6.11 & 8.415 & 6.21 \\
CP & 30.95 & 31.1 & 30.7 & 31.2 \\
CF & 8.15 & 8.03 & 8.345 & 7.935 \\
ADF & 10.055 & 10.305 & 13.175 & 10.31 \\
NDF & 15.725 & 13.415 & 11.2 & 11 \\
Macro-nutrients (\% in DW) & & & & \\
Ca & 1.419 & 1.304 & 1.427 & 0.674 \\
P & 0.287 & 0.425 & 0.222 & 0.125 \\
K & 0.571 & 0.762 & 0.69 & 0.291 \\
Mg & 0.062 & 0.116 & 0.054 & 0.065 \\
Na & 2.113 & 0.205 & 0.245 & 0.064 \\
Micro-nutrients (ppm) & & & & \\
Cu & 14.59 & 16.89 & 14.86 & 14.04 \\
Fe & 181.722 & 175.8 & 171.932 & 178.966 \\
Mn & $<0.001$ & $<0.001$ & 1.43 & $<0.001$ \\
$\mathrm{Zn}$ & 18.957 & 19.986 & 20.71 & 22.343 \\
\hline
\end{tabular}

Results are presented 'as is'.

The comparison of manured M. oleifera leaf proximate and mineral compositions from four locations of Namibia which are the Neudamm (NEU.) cultivated field, Neudamm Campus, Rundu (Kaisosi) and Windhoek City is found in Table 5. The Neudamm Field is an agronomic field about $1.5 \mathrm{~km}$ outside the Neudamm Campus 
where moringa was cultivated; Neudamm Campus has three old M. oleifera trees; Kaisosi is a location in Rundu Town about $750 \mathrm{~km}$ from Windhoek, the capital city of Namibia. Statistically, there were no significant differences $(\mathrm{P}>0.05)$ in $M$. oleifera leaves nutrient values among locations.

Table 5. Proximate and mineral compositions of M. oleifera leaves from four locations of Namibia $(\mathrm{g} / 100 \mathrm{~g})$

\begin{tabular}{lcccc}
\hline Nutrients (\% DM) & NEU. Field & NEU. Trees & Rundu (Kaisosi) & Windhoek \\
\hline Moisture & 5.975 & 6.16 & 6.11 & 6.3 \\
Ash & 10.775 & 13.55 & 10.64 & 15.5 \\
Fat & 5.695 & 5.81 & 5.64 & 4.45 \\
CP & 30.95 & 21.9 & 27.2 & 29 \\
CF & 8.15 & 9.73 & 7.76 & 8.15 \\
ADF & 10.055 & 13.88 & 8.91 & 8.7 \\
NDF & 15.725 & 14.77 & 16.39 & 15.52 \\
Macro-nutrients (\% DM) & & & & \\
Ca & 1.758 & 0.83 & 1.918 & 1.419 \\
P & 0.315 & 0.31 & 0.379 & 2.1125 \\
K & 0.701 & 1.755 & 0.783 & 0.2865 \\
Mg & 0.165 & 0.645 & 0.141 & 0.5705 \\
Na & 0.129 & 0.05 & 0.152 & 0.0615 \\
Micro-nutrients (ppm) & & & & \\
Cu & 12.371 & 9.4 & 10.512 & 14.585 \\
Fe & 182.97 & 150.5 & 196.843 & 181.722 \\
Mn & $<0.001$ & 76.5 & $<0.001$ & $<0.001$ \\
Zn & 20.711 & 20.5 & 10.596 & 18.957 \\
\hline
\end{tabular}

Results are presented 'as is'.

Tables 8 presents a comparison of $M$. oleifera leaves proximate and mineral compositions from four regions of Sub-Saharan Africa; namely, Central (Chad), East (Ethiopia), South (Namibia), and West (Nigeria). The data from the three countries were adopted from reports by Melesse (2011) from Ethiopia, Ogbe and Affifu (2012) from Nigeria and Mbailao, Mianpereum and Albert (2014) from Chad, while the data on Namibia were from the Neudamm Experimental Farm Moringa orchard.

Table 8. Comparative proximate and mineral composition of $M$. oleifera leaves from different African regions (g/100 g DW)

\begin{tabular}{lcccc}
\hline Nutrients (\% in DW) & Chad & Ethiopia & Namibia & Nigeria \\
\hline Moisture & $20.92(\mathrm{DM})$ & --- & 6.16 & 3.21 \\
Ash & 6.73 & 13.2 & 13.55 & 7.93 \\
Fat & 2.34 & 6.73 & 5.81 & 2.11 \\
$\mathrm{CP}$ & 32.06 & 28.9 & 21.9 & 17.01 \\
$\mathrm{CF}$ & 8.07 & 8.51 & 9.73 & 7.09 \\
$\mathrm{ADF}$ & --- & 12.1 & 13.88 & --- \\
$\mathrm{NDF}$ & --- & 16.7 & 14.77 & --- \\
$\mathrm{Macro}-$ nutrients (\% in DW) & & & & \\
$\mathrm{Ca}$ & 1.23 & 2.62 & 0.83 & 1.91 \\
$\mathrm{P}$ & 0.32 & 0.43 & 0.31 & 30.15 \\
$\mathrm{~K}$ & 1.73 & 2 & 1.755 & 0.79 \\
$\mathrm{Mg}$ & 0.39 & 0.56 & 0.645 & 0.38 \\
$\mathrm{Na}$ & 0.08 & 0.03 & 0.05 & 192.95 \\
$\mathrm{Micro}-$ nutrients (ppm) & & & & \\
$\mathrm{Cu}$ & 9.07 & --- & 9.4 & 6.18 \\
$\mathrm{Fe}$ & 97.12 & --- & 150.5 & 107.48 \\
$\mathrm{Mn}$ & 29.33 & --- & 76.5 & 81.65 \\
$\mathrm{Zn}$ & 29.14 & --- & 20.5 & 60.06 \\
\hline
\end{tabular}

Sources: Melesse (2011), Ogbe and Affifu (2012) and Mbailao et al. (2014); Results are presented 'as is'. 


\subsection{Comparison of M. ovalifolia Nutrient Compositions at Treatment Levels}

The comparison of $M$. ovalifolia leaf proximate and mineral composition within blocks using the control block in a one-sample t-test is found Table 9. Just as M. oleifera, M. ovalifolia was transplanted in four blocks in which block1 was the control $(0 \mathrm{~g})$, and block2 (100 g), block3 (200 g) and block4 (300 g) - the experimental blocks for phosphorus and nitrogen fertilizers application (See Table 3 ). There were no significant differences $(P>0.05)$ in moisture, ash, fat, $\mathrm{CP}, \mathrm{ADF}$ and NDF contents between the control (block1) and the experimental blocks (block2, block3 and block4); except for CF which showed a different $(\mathrm{P}<0.05)$ between the control block and experimental blocks. Similarly, there were no significant differences $(\mathrm{P}>0.05)$ in $\mathrm{Ca}, \mathrm{K}, \mathrm{Mg}, \mathrm{P}, \mathrm{Cu}$ and $\mathrm{Mn}$ mineral composition within blocks, except for $\mathrm{Na}, \mathrm{Fe}$ and $\mathrm{Zn}$ that showed different $(\mathrm{P}<0.05)$ between the control block and experimental blocks.

Table 9. Comparative proximate and mineral composition of M. ovalifolia leaves within treatments (g/100 g)

\begin{tabular}{lcccccc}
\hline \multirow{2}{*}{ Nutrient (\% in DW) } & \multicolumn{2}{c}{ Blocks Means } & Std. Deviation & Std. Error Mean & $\mathrm{t}$ & P-values \\
\cline { 2 - 4 } & Control & Fertilized & & & & \\
\hline Moisture & 6.37 & 6.143 & 0.29687 & 0.17140 & -1.322 & 0.317 \\
Ash & 12.61 & 10.887 & 1.35463 & 0.78210 & -2.203 & 0.158 \\
Fat & 6.17 & 5.670 & 1.03793 & 0.59925 & -0.834 & 0.492 \\
CP & 31.5 & 27.733 & 3.6074 & 2.0827 & -1.809 & 0.212 \\
CF & 10.08 & 7.917 & 1.18095 & 0.68182 & -3.173 & 0.087 \\
ADF & 12.87 & 11.410 & 1.24852 & 0.72083 & -2.025 & 0.180 \\
NDF & 16.72 & 12.980 & 2.84317 & 1.64150 & -2.278 & 0.150 \\
Macro-nutrients (\% in DW) & & & & & \\
Ca & 1.541 & 1.768 & 0.172 & 0.099 & 2.288 & 0.149 \\
P & 0.362 & 0.370 & 0.092 & 0.053 & 1.736 & 0.225 \\
K & 0.735 & 0.816 & 0.080 & 0.047 & -3.897 & 0.060 \\
Mg & 0.274 & 0.151 & 0.055 & 0.031 & 1.192 & 0.356 \\
Na & 0.141 & 0.251 & 0.160 & 0.093 & 0.158 & 0.889 \\
Micro-nutrients (ppm) & & & & & & \\
Cu & 15.112 & 12.427 & 3.194 & 1.844 & -1.456 & 0.283 \\
Fe & 184.834 & 171.368 & 26.748 & 15.443 & -0.872 & 0.475 \\
Mn & 0.001 & 0.001 & 0.000 & 0.000 & 1.961 & 0.189 \\
Zn & 12.65 & 13.798 & 1.0137 & 0.585 & 2.288 & 0.149 \\
\hline
\end{tabular}

Results are presented 'as is'.

Table 10 compares the proximate and mineral composition of $M$. ovalifolia leaves within blocks as the nitrogen and phosphorus fertilizers were applied. The same experimental design was used as in the case of $M$. oleifera (see Table 3).

Table 10. Comparative proximate and mineral composition of $M$. ovalifolia leaves within treatments $(\mathrm{g} / 100 \mathrm{~g})$

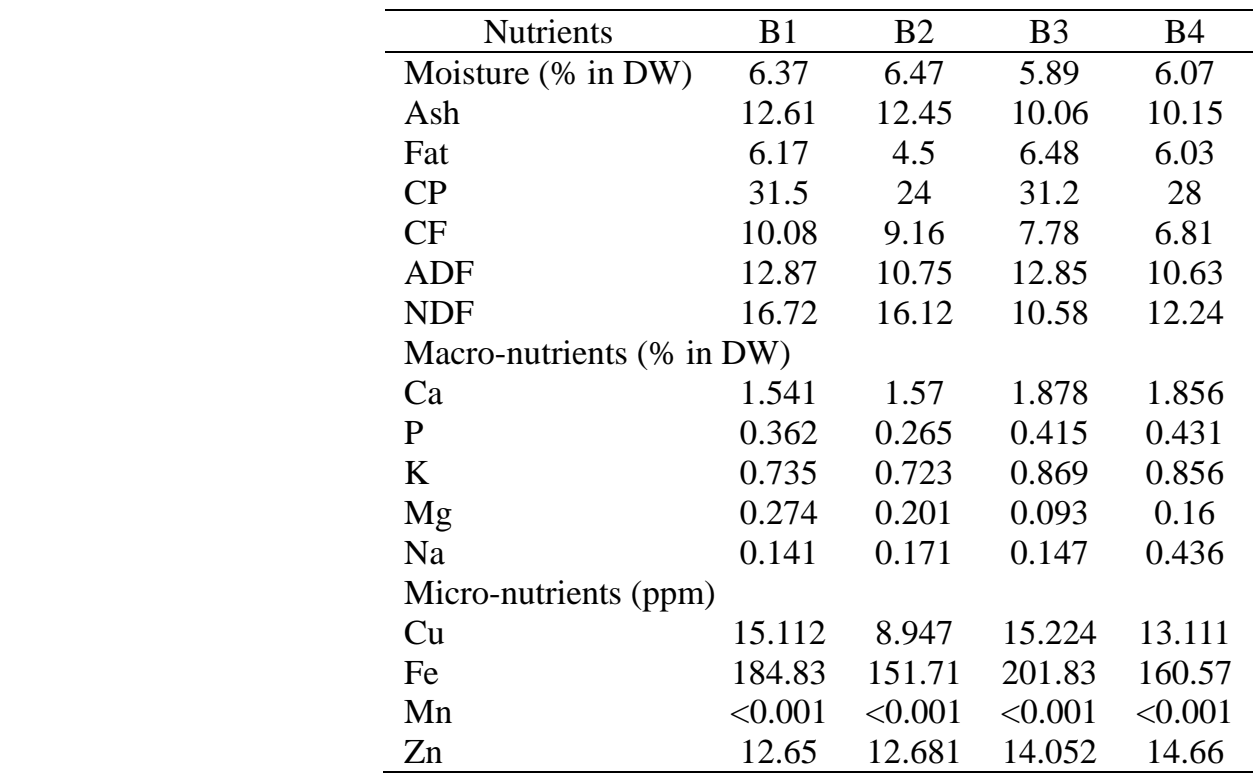

Results are presented 'as is'. 


\section{Discussion}

\subsection{Nutrient Composition of M. oleifera and M. ovalifolia}

The CP levels were the highest in both M. oleifera and M. ovalifolia than other parameters in the proximate compositions, followed by NDF, ADF, ash, CF, fat and moisture (See Table 1), which concurs with Fagwalawa, Yahaya and Umar (2014) report that CP was highest in their proximate composition study with M. oleifera. Among the two species, M. oleifera had higher overall mean value in CP (30.988\%) than M. ovalifolia (28.68\%). Crude protein in both Moringa species in this research was higher than $27.1 \%$ and $18.49 \%$ as reported by Fuglie (2001) and Mutiara, Estiasih and Sriwahyuni (2013), respectively for M. oleifera. On the other hand, Fagwalawa et al. (2014) reported higher CP (43.53\%) value of M. oleifera leaves than the current study values. According to Mpofu (2004), CP content of less than 7\% is known to limit forage intake and small ruminants performance, which normally occurs during dry months leading to the search for alternative protein sources. The CP content in the both Moringa species ranges from 28.86 to $30.988 \%$; thus, making all these species good alternative sources for protein supplements. However, M. ovalifolia had higher content of NDF (13.92\%), ADF (11.78\%) and ash $(11.32 \%)$ than M. oleifera, which makes M. ovalifolia a better energy and mineral source. Tisch (2006) explained that structural carbohydrate, measured as NDF, constitute the cell wall of a plant and includes the fiber fractions of cellulose, hemicellulose, lignin and neutral detergent fiber insoluble protein (NDFIP). When a feedstuff's ADF is high, it will be of low digestibility to animals. On the other hand, the nutrient values obtained were higher than those obtained in Nigeria for M. oleifera leaves by Ogbe and Affifu (2011). Moisture content of 6.2\% and $6.025 \%$ in M. ovalifolia and M. oleifera respectively was lower than the 7.5\% reported by Fuglie (2001). Moisture (6.98\%) and Fat (4.19\%) of M. oleifera as reported by Romuald et al. (2016) are in agreement with the present study result, but CP $(25.8 \%)$ was much lower than that reported by Fagwalawa et al. in 2014 (43.53\%). On the other hand, in the report by Fayomi et al. (2014) ash (4.48\%), CP $(15.93 \%)$ values were much lower compared to the values obtained in the current study report, while CF $(11.84 \%$ against $8.458 \%$ and $8.115 \%)$ was higher.

The mineral composition of M. oleifera and M. ovalifolia leaves analysis comprised of $\mathrm{Ca}, \mathrm{P}, \mathrm{F}, \mathrm{Mg}, \mathrm{Na}, \mathrm{Cu}, \mathrm{Fe}$, $\mathrm{Mn}$ and $\mathrm{Zn}$ and was divided into macro-nutrients and micro-nutrients (See Table 1). Macro-minerals are needed in relatively larger amount in an animal diet while the micro-minerals (trace elements) are needed in very small amount in diets (Jurgens, Bregendahl, Coverdale, \& Hansen, 2012). Iron had the highest mean value of 174.7 ppm and $177.10475 \mathrm{ppm}$ followed by $\mathrm{Zn}(13.51 \mathrm{ppm}$ and $20.49887 \mathrm{ppm})$ and $\mathrm{Cu}(13.1 \mathrm{ppm}$ and $15.09338 \mathrm{ppm})$ with $\mathrm{Mn}(0.001 \mathrm{ppm}$ and $0.358 \mathrm{ppm})$ being the lowest for M. oleifera and M. ovalifolia correspondingly. Iron (28.2) and $\mathrm{Cu}(0.57)$ values reported by Fuglie (2001) were lower than the values found in this study (see Table 1). However, $\mathrm{Ca}, \mathrm{K}, \mathrm{Mg}$ and $\mathrm{P}$ were higher than those in the current study. For macro-nutrients, $\mathrm{Ca}$ (1.711\% for M. ovalifolia and $1.206 \%$ for M. oleifera) was higher while $\mathrm{P}, \mathrm{K}, \mathrm{Mg}$ and $\mathrm{Na}$ were all $<1 \%$ for both species. An elemental composition of M. oleifera leaves from Chad reported by Mbailao et al. (2014) found similar values to the current study of $\mathrm{Na}(0.08 \%), \mathrm{K}(1.73 \%), \mathrm{Ca}(1.23 \%), \mathrm{Mg}(0.39 \%), \mathrm{P}(0.32 \%), \mathrm{Fe}$ (97.12 ppm), Mn (29.33 ppm), $\mathrm{Zn}(19.14 \mathrm{ppm})$ and $\mathrm{Cu}(9.07 \mathrm{ppm})$, except for $\mathrm{Fe}$ and $\mathrm{Cu}$ which were much lower compared to the current findings (see Table 1). However, Mn was higher than what was found in that previous work.

M. oleifera leaves had higher TDN content $(67 \%)$ and ME content $(11 \mathrm{MJ} / \mathrm{kg})$ while DE $(12 \mathrm{MJ} / \mathrm{kg})$ was equal in both species of Moringa (See Table 2), which is higher than $9.2 \mathrm{MJ} / \mathrm{kg}$ of ME from an extracted M. oleifera leaves reported by Makkar and Becker (1996). Total digestible nutrient had the highest total mean and standard error of the mean (SEM) (64.5\% and $4.419 \%$ respectively), followed by DE mean (12\% MJ $/ \mathrm{kg}$ ) with zero SEM, ME mean and SEM contents (10.5\% and $0.177 \%$, respectively). Tannins (tannic acid) content was higher in $M$. ovalifolia leaves (4.4\%) than in M. oleifera leaves (3.9\%) with a total mean of $4.15 \%$, and SEM of $0.044 \%$. The tannins results of this study concurred with the condensed tannins result (3.2\%) of M. oleifera leaves analysed by Moyo, Masika, Hugo and Muchenje (2010). In addition, Ojiako (2014) study on the quantitative analysis of phytochemical compounds present in the leaf extract of M. oleifera shows $8.22 \%$ tannins content, which is higher than the values found in this research.

\subsection{Comparison of M. oleifera Leaves Nutritional Composition}

The proximate composition M. oleifera leaves harvested from four blocks (See Table 3) showed that the means of moisture $(6.042 \%)$, fat $(6.912 \%), \mathrm{ADF}(11.263 \%)$ and $\mathrm{CP}(31 \%)$ nutrient values were higher for block2, block 3 and block 4 in comparison to the control block (block1), and reveals a progressive increment as the level of applied fertilizers increased. Contrary, CF (6.15\%), ash (10.775\%) and NDF (15.725\%) were higher in the control block, an indication that $M$. oleifera naturally contains high CF, ash and NDF and hence does not require fertilizer application as discussed by Fuglie (2001). Crude fiber in this study was lower than $11.84 \%$ reported by 
Fayomi et al. (2014); however, CP and ash were higher in this study than what they reported (15.93\% and $4.89 \%$ against $31 \%$ and $10.775 \%$ ). The moisture and ash contents $6.98 \%$ and $8.35 \%$ reported by Romuald et al. (2016) from Ivory Coast concur with the results of this study but the CP they reported was lower (25.81\% against $31 \%)$. For the mineral composition as seen in Table 3, the means of $\mathrm{Mg}(0.078 \%), \mathrm{Mn}(0.477 \mathrm{ppm}), \mathrm{K}(0.581 \%), \mathrm{Cu}$ $(15.263 \mathrm{ppm})$, and $\mathrm{Zn}(21.01 \mathrm{ppm})$ nutrient values were higher for blocks where fertilizers were applied in comparison to the control block. Phosphorus (0.2865\%), Ca (1.419\%), $\mathrm{Na}(2.1125 \%)$ and $\mathrm{Fe}(181.722 \%)$ were higher in the control block, which is an indication that M. oleifera naturally contains high levels of $\mathrm{P}, \mathrm{Ca}, \mathrm{Na}$ and $\mathrm{Fe}$. The other hand, the soil readily contains $\mathrm{P}, \mathrm{Ca}$ and $\mathrm{Na}$ that might have been taken by the trees of the control block although Fe was not determined as seen in Table11.

Table 11. Soil nutrients and properties of the moringa orchard

\begin{tabular}{|c|c|c|c|}
\hline \multirow[t]{2}{*}{ Type of analysis } & \multirow[t]{2}{*}{ Units } & \multicolumn{2}{|c|}{ Sample collection depths } \\
\hline & & $0-30 \mathrm{~cm}$ depth & $30-60 \mathrm{~cm}$ depth \\
\hline $\mathrm{pH}$ & & 7.22 & 7.67 \\
\hline $\begin{array}{l}\text { Electrical Conductivity or Soluble Salts } \\
\text { (EC) }\end{array}$ & $\mathrm{uS} / \mathrm{cm}$ & 80 & 87 \\
\hline Organic Matter $(\mathrm{OM})$ & $\%$ & 0.87 & 0.65 \\
\hline Nitrogen & $\%$ & & \\
\hline Phosphorus (P) & ppm & 24.60 & 12.30 \\
\hline Potassium (K) & $\mathrm{ppm}$ & 295 & 384 \\
\hline Calcium (Ca) & $\mathrm{ppm}$ & 572 & 586 \\
\hline Magnesium $(\mathrm{Mg})$ & ppm & 95 & 107 \\
\hline Sodium $(\mathrm{Na})$ & $\mathrm{ppm}$ & 5 & 8 \\
\hline Carbonate $\left(\mathrm{CO}_{3}^{2-}\right)$ & estimate & None & None \\
\hline Texture & --- & Loamy sand & Loamy sand \\
\hline Sand & $\%$ & 84.2 & 82.1 \\
\hline Silt & $\%$ & 8.2 & 9.7 \\
\hline Clay & $\%$ & 7.6 & 8.1 \\
\hline
\end{tabular}

Among the four blocks (See Table 4), CP values were almost the same [B3 (30.7), B1 (31.1), B2 (31.1) and B4 (31.2)], which indicates that $M$. oleifera needs little or no inorganic fertilizers to maintain its protein content level. NDF had a declining increase in values as the fertilizer levels increased. This means that the more levels of fertilizers one applies, the lower nutrients it yields. For ADF, block3 had the highest nutrient value (13.175\%) which was followed by B4 (10.31\%), B2 (10.305\%) and B1 (10.055\%) respectively. The highest Ash value was found in B2 (11.07), followed by B1 $(10.775 \%)$, B4 (10.57\%) and B3 (10.195\%). Ash is the total mineral content of plants or animals (Jurgens et al., 2012). The control (B1) had the highest value of Fe (181.7215 ppm), followed by B4 (178.9855 ppm), B2 (175.8\% ppm) and B3 (171.932 ppm), consecutively. This implies that $M$. oleifera naturally contains $\mathrm{Fe}$ in large quantity and fertilizer application may have little or no effect at all. Interestingly, $\mathrm{Zn}$ as the second highest mineral component, increased in values as the levels of fertilizers increased according to blocks, that is, B1 (18.957 ppm), B2 (19.986 ppm), B3 (20.71 ppm) and B4 (22.3425 $\mathrm{ppm})$. This means that an increase in fertilizer levels resulted in an increment in $\mathrm{Zn}$ values. Just as $\mathrm{Fe}, \mathrm{Cu}$ increased randomly in that B2 (16.891 ppm), B3 (14.8595 ppm), B1 (14.585 ppm) and B4 (14.038 ppm). Minerals make up only a relatively small amount of the diet of animals. Nevertheless, they are vital to the animals' diet, their supplementation is required in most situations for high-producing animals (Church, 1991).

The comparison of manured M. oleifera leaf proximate composition from four locations of Namibia as shown in Table 5 included parameters such as moisture, ash, fat, CP, CF, ADF and NDF. The Neudamm cultivated field $M$. oleifera leaves had the highest nutrient values in NDF (14.77\%) and CP (30.95\%), followed by leaves harvested from Neudamm Campus trees in fat (6.81\%), CF (9.73\%) and NDF (13.88\%); leaves from Windhoek City had higher values of moisture (6.3\%) and second in CP (29\%), while leaves from Rundu (Kaisosi) had the highest content only in NDF (16.39\%). For the minerals considered in Table 5, Fe, $\mathrm{Zn}, \mathrm{Cu}$ and $\mathrm{Mn}$ had higher values, and Neudamm Campus trees had the highest Fe (196.843 ppm), followed by those from Rundu, Kaisosi (182.97 $\mathrm{ppm})$, from Neudamm cultivated field (181.7215 ppm) and from Windhoek City (150.5). The highest values for $\mathrm{Cu}$ were found in Windhoek City leaves (14.585 ppm), Neudamm cultivated field leaves (12.371 ppm), Rundu, Kaisosi leaves (10.512 ppm) with Neudamm Campus leaves being the lowest (9.4 ppm). Concerning Zn values, Neudamm Campus leaves had 10.596 ppm, Neudamm cultivated field leaves - $18.957 \mathrm{ppm}$, Windhoek City leaves - 20.5 ppm and Rundu Kaisosi leaves - 20.711 ppm. Minerals such as $\mathrm{Ca}, \mathrm{P}, \mathrm{K}, \mathrm{Mg}, \mathrm{Na}$ and $\mathrm{Mn}$ were very 
low in values. On the contrary, M. oleifera leaves from Windhoek City had higher Mn values (76.5 ppm) as an outlier while leaves from other locations had $<0.001 \mathrm{ppm}$ Mn values. Moringa oleifera leaves from trees found in the four locations of Namibia have quite similar nutrient profiles, which means that location has very little or no impact on moringa nutrient contents.

Moringa oleifera tree is native to India but has been planted around the world and is naturalized in many countries and has very high concentration of nutrients (Fuglie, 2001; Sanchez et al., 2006; Prince, 2007), of which Africa is no exception. The comparison of M. oleifera leaves proximate compositions from the four regions of sub-Saharan Africa as seen in Table 8 indicates that moisture ranges from $3.21 \%$ to $6.16 \%$ with leaves from Nigeria having less moisture percentage than those from Namibia while leaves from Chad had 20.92\% moisture content. Leaves from Namibia and Ethiopia had the highest content of ash $(13.55 \%$ and $13.2 \%$ respectively) with those from Chad having the lowest moisture content (6.73\%). Leaves from Ethiopia and Namibia had the highest content of fat (6.73\% and 5.81\% respectively) with those from Chad and Nigeria having $2.11 \%$ and $2.34 \%$ fat content. Leaves from Chad and Ethiopia had higher CP (32.06\% and 28.9\%) while those from Namibia and Nigeria had lower CP content (21.9\% and 17.01\%). Leave crude fiber had similar content across the four regions and was ranging from $7.09 \%$ to $9.73 \%$ with leaves from Namibia having the highest content and Nigeria, the lowest. Leaves from Namibia had higher contents in ADF (13.88\%) and NDF (14.77\%) than those from Ethiopia (8.49\% and $11.40 \%$ for ADF and NDF, respectively). These results were reported by Melesse (2011) from Ethiopia, Ogbe and Affifu (2011) from Nigeria and Mbailao et al. (2014) from Chad. Leaves from Namibia had the best in most nutritional values except for fat and CP for which Ethiopia and Chad had higher contents correspondingly. Among the four representative nations, Nigeria had the lowest proximate nutritional values.

Moring oleifera leaves macro-nutrients ( $\mathrm{Ca}, \mathrm{P}, \mathrm{K}, \mathrm{Mg}$ and $\mathrm{Na}$ ) and micronutrients $(\mathrm{Cu}, \mathrm{Fe}, \mathrm{Mn}$ and $\mathrm{Zn}$ ) for the four regions of Africa are found in Table 8. Moringa leaves from Nigeria had the highest content of macro-nutrients such as $\mathrm{Ca}(1.91 \%), \mathrm{P}(30.15 \%)$ and $\mathrm{Na}$ (192.95\%), while leaves from Chad, Ethiopia and Namibia had quite similar values. Concerning micro-nutrient contents, leaves from Nigeria also had the highest values of $\mathrm{Mn}(81.65 \mathrm{ppm})$ and $\mathrm{Zn}(60.06 \mathrm{ppm})$; leaves from Namibia had the highest content of Fe (150.5 ppm). On the other hand, leaves from Chad and Namibia had the higher values of $\mathrm{Cu}$ (9.07 ppm and $9.4 \mathrm{ppm}$ ) respectively, while those from Nigeria had the lowest $\mathrm{Cu}$ values. However, moringa leaves from Ethiopia were not analysed for micro-nutrients and therefore had unknown contents of micro-nutrients. The slight differences in mineral composition might be attributed to soil-nutrient compositions at production sites as discussed by Grusak (2001). Interestingly, M. oleifera maintains its nutritional values almost at the same level despite regional ecological differences among the four countries.

\subsection{Comparison of M. ovalifolia Leaves Nutrient Composition at Treatment Levels}

The comparison of M. ovalifolia leaf proximate and mineral compositions (See Table 9) revealed that leaves from the control (block1) had higher moisture content (6.37\%), ash (12.61\%), Fat (6.17\%), CP (31.5\%), CF $(10.08 \%) \mathrm{ADF}(12.87 \%)$ and NDF (16.72\%) values in comparison to the experimental blocks (block2, block3 and block4). The higher proximate composition of leaves from block1 is a clear indication that M. ovalifolia does not need both phosphorus and nitrogen fertilizers to produce quality/nutrient-rich leaf biomass. Moringa ovalifolia contains a high level of CP like M. oleifera under organic production, which makes it a better alternative feed supplement for animals while avoiding human-livestock conflict and reducing the production/purchase cost. Church (1991) and Tisch (2006) emphasized that protein sources for livestock ration are more expensive than carbohydrate sources and the most costly component of a finished feed. Church (1991) also mentioned that most plant $\mathrm{CP}$ sources (beans, alfalfa, coconut, sunflower, and so on) range from $20 \%$ to 40+ \%, which both Moringa species have (CP contents of $31 \%$ and $31.5 \%$ for M. oleifera and M. ovalifolia respectively). Between the blocks, $\mathrm{Mg}(0.078 \%), \mathrm{Mn}(0.477 \mathrm{ppm}), \mathrm{K}(0.581 \%), \mathrm{Cu}(15.263 \mathrm{ppm})$, and $\mathrm{Zn}$ (21.013 ppm) mineral values were higher in leaves from experimental blocks (blocks 2 to 4 ) than the values in the leaves from block1(control). However, $\mathrm{P}(0.2865 \%), \mathrm{Ca}(1.419 \%), \mathrm{Na}(2.1125 \%)$ and $\mathrm{Fe}(181.722 \mathrm{ppm})$ were higher in block1. These higher mineral values in the leaves of the control block may be attributed to the soil mineral contents (See Table 11).

Moringa ovalifolia seedlings were transplanted in four blocks with four treatment levels: B1 (0 g), block2 (100 $\mathrm{g})$, block3 (200 g) and block4 (300 g) as in the case of M. oleifera (See Table 4). The proximate composition (See Table 10) of M. ovalifolia leaves at block levels showed that block1 had the highest values in ash (12.61\%), CP (31.5\%), CF (10.08\%), ADF (12.87\%) and NDF (16.72\%). Leaves from block2 had the second highest content of moisture $(6.47 \%)$, ash (12.45\%), CP $(9.16 \%)$ and NDF $(16.12 \%)$; followed by leaves from block3 fat content $(6.48 \%)$, CF content (7.78\%) and ADF content (12.85\%), while leaves from block4 had the lowest CF 
$(7.935 \%)$ and NDF (11\%) values respectively. The high nutrient values in leaves from block1 is an indication that $M$. ovalifolia, like its counterpart $M$. oleifera is a nutrient-rich plant source with less demand in fertilizers and can serve as a perfect supplement for ruminants. In addition, CF showed declining nutrient values as the fertilizer levels increased (block $1=10.08$, block $2=9.16$, block $3=7.78$ and block $4=6.81$ ). Since leaves from the control block had the highest content of nutrients besides Fat and moisture, it is evident that M. ovalifolia can be grown without phosphorus and nitrogen fertilizers and maintain high nutrient content for use as an animal supplement as suggested by Fuglie (2001).

Among minerals as found in Table 10, only $\mathrm{Fe}, \mathrm{Cu}$ and $\mathrm{Zn}$ were found in large quantities while $\mathrm{Ca}$ was $<2 \%$; $\mathrm{Mg}, \mathrm{Na}$ and $\mathrm{P}$ were $<1 \%$ and $\mathrm{Mn}$ was $<0.001 \mathrm{ppm}$ for all blocks (B1, B2, B3 and B4). Leaves from block three (B3) had the highest mineral composition with $\mathrm{Fe}(201.827 \mathrm{ppm})$ and $\mathrm{Cu}(15.224 \mathrm{ppm})$; followed by B1 in which $\mathrm{Fe}(184.834 \mathrm{ppm})$ and $\mathrm{Cu}(15.112 \mathrm{ppm})$ were the highest micro-nutrients. Leaves from B4 only had the highest content in $\mathrm{Zn}(14.66 \mathrm{ppm})$, while those from B2 had the lowest elements. Zinc had increasing values as the fertilizer levels increased: $\mathrm{B} 1=12.65 \%, \mathrm{~B} 2=12.681 \%, \mathrm{~B} 3=13.052 \%$ and $\mathrm{B} 4=14.66 \%$ respectively. This implies that $\mathrm{Zn}$ composition could be dependent on the levels fertilizers.

\section{Conclusion}

Moringa plant species are nutritious and contain almost all the essential nutrients needed by humans and livestock for growth and development. Substantial amount of macro- and micro-nutrients were found in both Moringa species making it fit to be used as feed supplements. Their proximate composition showed desirable nutrients for the formulation of animal feeds. Although there is a possible human-livestock conflict in the use of M. oleifera, if adopted by livestock farmers, both M. oleifera and M. ovalifolia have the potential to eliminate the purchasing of animal feed supplements since they contain all the essential nutrients. This problem can be solved by replacing $M$. oleifera by $M$. ovalifolia (for which there in no competition) as an animal feed supplement. Thus, it will improve livestock production as it will be readily available on the farm for supplementation during winter and drought periods when grasses and browses in rangelands have low nutritional values. Moringa oleifera leaves maintain their nutritional values despite the geographical or ecological differences in its cultivation (no data are available for M. ovalifolia). Therefore, the cultivation of Moringa as a nutrient-rich plant species should be encouraged, and its uses and benefits as a food and/or feed for humans and "livestock improvement".

\section{Acknowledgement}

This study was financially supported by Namibia Students Financial Assistance Fund (NSFAF) and South Collaborative Research Programme through the National Commission on Research and Technology (NCRST). This article is part of a PhD research undertaken by Morlu Korsor at the University of Namibia, Department of Animal Science.

\section{References}

AgriLASA. (1993). Agri-Laboratory Association of Southern Africa (AgriLASA). AgriLASA.

Alhakman, F., Kumar, S., \& Khan, S. (2013). Estimation of total phenolic content, in-vitro antioxidant and anti-inflammatory activity of flowers of Moringa oleifera. Asian Pacific Journal of Tropical Biomedicine, 3(8), 623-627. https://doi.org/10.1016/S2221-1691(13)60126-4

AOAC. (2006). AOAC INTERNATIONAL: Final report and executive summaries from the AOAC International task force on best practices in microbiological methodology. AOAC INTERNATIONAL. Retrieved from http://www.fda.gov/downloads/Food/FoodScienceResearch/UCM088702.pdf

Beukes, P. (2017). Average annual rainfall of Neudamm Experimental Farm from 1974 to 2016 (Meteorological) (pp. 1-2). Namibia: University of Namibia.

Church, D. (1991). Livestock feeds and feeding. Prentice Hall, New Jersey.

Cunniff, P. (Ed.). (1996). Official methods of analysis of AOAC International (16th ed., Vol. 1). Arlington, Virginia, USA: AOAC INTERNATIONAL.

Curtis, B., \& Mannheimer, C. (2005). Tree Atlas of Namibia. Windhoek, Namibia: The National Botanical Institute.

Fagwalawa, L., Yahaya, S., \& Umar, D. (2014). A comparative proximate analysis of bark, leaves and seeds of Moringa oleifera. International Journal of Basic and Applied Chemical Sciences, 5(4), 56-62.

Fayomi, A., Ahmed, A., Musa, U., Salami-Shinaba, J., Ogedegbe, S., \& Akanni, K. (2014). Moringa multi-nutrient blocks: formulation, production, and feeding trial under a tropical environment. International 
Journal of Science, Environment and Technology, 3(1), 67-84.

Foidl, N., Makkar, H., \& Becker, K. (2001). The potential of Moringa oleifera for agricultural and industrial uses (pp. 45-76). Presented at the What development potential for Moringa products, Dar Es Salaam: CTA and CWS. Retrieved from http://miracletrees.org/potential-of-morionga-oleifera.html

Foidl, N., Makkar, H., \& Becker, K. (2011). The potential of Moringa oleifera for agricultural and industrial uses. Retrieved from http://www.empaeg.com/UserFiles/File19947.pdf

Fuglie, L. (2001). The miracle tree: the multiple attributes of Moringa. Dakar, Senegal: CTA.

Galyean, M. (2010, May). Laboratory procedures in animal nutrition research. Texas Tech University, Lubbock. Retrieved from https://www.depts.ttu.edu/afs/home/mgalyean/lab_man.pdf

Grusak, M. (2001). Plant Macro- and Micronutrient Minerals. Nature Publishing Group. Retrieved from http://rubisco.ugr.es/fisiofar/pagwebinmalcb/contenidos/Tema11/macro\%20y\%20micronutrient.pdf

Hiawacha Bey, H. (2010). All things Moringa: the story of an amazing tree of life. Http://Www.allthingsmoringa.com/eBook.pdf, 1-42.

Hochmuth, G., Maynard, D., Vavrina, C., Hanlon, E., \& Simonne, E. (2015). Plant Tissue Analysis and Interpretation for Vegetable Crops in Florida. IFAS Extension, University of Florida. Retrieved from http://edis.ifas.ufl.edu/pdffiles/EP/EP08100.pdf

Joshua, R., \& Vasu, V. (2013). Characteristics of stored rain water and its treatment technology using moringa seeds. International Journal of Life Sciences Biotechnology and Pharma Research, 2(1), 155-174.

Jurgens, M., Bregendahl, K., Coverdale, J., \& Hansen, S. (2012). Animal feeding and nutrition. United States of America: Kendall Hunt Publishing Company.

Madukwe, E., Ezeugwu, J., \& Eme, P. (2013). Nutrient composition and sensory evaluation of dry Moringa oleifera aqueous extract. International Journal of Basic \& Applied Sciences, 13(03), 100-102.

Makkar, H, \& Becker, K. (2007). Nutrients and anti-quality factors in different morphological parts of the Moringa oleifera tree. Cambridge University Press, 123, 311-322.

Makkar, HPS, \& Becker, K. (1996). Nutritional value and antinutritional components of whole and ethanol extracted Moringa oleifera leaves. Animal Feed Science and Technology on ELSEVIER, 63, 211-228.

Mbailao, M., Mianpereum, T., \& Albert, N. (2014). Proximal and Elemental Composition of Moringa oleifera (Lam) Leaves from Three Regions of Chad. Journal of Food Resource Science, 3, 12-20. https://doi.org/10.3923/jfrs.2014.12.20

Mbikay, M. (2012). Therapeutic potential of Moringa oleifera leaves in chronic hyperglycemia and dyslipidemia: a review. Frontiers in Pharmacology. https://doi.org/10.3389/fphar.2012.00024

Melesse, A. (2011). Comparative assessment on chemical compositions and feeding values of leaves of Moringa stenopetala and Moringa oleifera using in vitro gas production method. Ethiopia Journal of Applied Science Technology, 2(2), 31-41.

Mendieta, B., Reyes, N., \& Rodriquez, R. (2007, June 25). Successful experiences of on the use of Moringa oleifera in animal feeding. Retrieved from http://redmarango.una.edu.ni/documentos/20-Bryan-Moringa-pres-Vietnam-final-version.pdf

Moyo, B., Masika, P., Hugo, A., \& Muchenje, V. (2010). Nutritional characterization of Moringa (Moringa oleifera Lam.) leaves. African Journal of Biotechnology, 10(60), 12925-12933.

Mpofu, I. (2004). Applied animal feed science and technology. (L. Mutewa \& C. Vengesai, Eds.). UPFRONT PUBLISHING ltd LEICESTERSHIRE.

Mutiara, T., Estiasih, H., \& Sriwahyuni, E. (2013). Effect of Blanching Treatments against Protein Content and Amino Acid Drumstick Leaves (Moringa oleifera). Journal of Food Research, 2(1). https://doi.org/10.5539/jfr.v2n1p101

Ogbe, A., \& Affifu, J. (2011). Proximate study, mineral and anti-nutrient composition of Moringa oleifera leaves harvested from Lafia, Nigeria: Potential benefits in poultry nutrition and health. Journal of Microbiology, Biotechnology and Food Sciences, 1(3), 296-308.

Ojiako, E. (2014). Phytochemical analysis and antimicrobial screening of Moringa oleifera leaves extract. The International Journal of Engineering and Science, 3(3), 32-35. 
Ojukwu, A. (2012, January). Moringa as livestock feed. West Africa Insight.

Olson, M. E. (2001). Introduction to the Moringa family. In L. Fuglie (Ed.), The miracle tree: The multiple attributes of Moringa (pp. 11-28). Dakar, Senegal: CTA and CWS.

Pace Project. (n.d.). Planting fodder banks for livestock. Pace Project, 37. Retrieved from http://www.doc-developpement-durable.org/file/programmes-de-sensibilisations/forets-protection/planting fodder_PACE.pdf

Pallett, J. (1994). Understanding the Oshana environment. Windhoek, Namibia: GAMSBERG MACMILLAN PUBLISHERS LTD.

Prince, M. (2007). ECHO Technical Note: The Moringa tree, 1-9. Retrieved from http://chenetwork.org/files_pdf/Moringa.pdf

Romuald, M., Ysidor, K., Daouda, S., Adama, C., Pierre, E., Olivier, C., \& Marius, B. (2016). Nutritive compounds from leaves of Moringa oleifera $\mathrm{L}$. and beans of Vigna unguiculata W. for improvement of the meal deriving with new shoots of Borassus aethiopum M. in Côte d'Ivoire. International Journal of Environmental \& Agriculture Research, 2(6), 64-74.

Sanchez, N., Ledin, S., \& Ledin, I. (2006). Biomass production and chemical composition of Moringa oleifera under different management regimes in Nicaragua. Springer, 66, 231-242. https://doi.org/10.1007/s10457-005-8847-y

Sanchez-Machado, D., Núñez-Gastélum, J., Reyes-Moreno, C., Ramírez-Wong, B., \& López-Cervantes, J. (2010). Nutritional quality of edible parts of Moringa oleifera. Food Analytical Methods, 3, 175-180. https://doi.org/10.1007/s12161-009-9106-z

Sijssens, P. (2014). Evaluation of MCA Namibia's Livestock Support Activity (Final Report No. $\mathrm{MCA} / \mathrm{COM} / \mathrm{RCQ} / 5 \mathrm{E} 01001)$ (p. 48). Namibia. Retrieved from http://www.mcanamibia.org/files/files/Final\%20Report\%20LS.pdf

Soliva, C., Kreuzer, M., Foidl, G., Machmuller, A., \& Hess, H. (2005). Feeding value of whole and extracted Moringa oleifera leaves for ruminants and their effects on ruminal fermentation in vitro. Animal Feed Science and Technology, 118, 47-62. https://doi.org/10.1016/j.anifeedsci.2004.10.005

Tisch, D. (2006). Animal feeds, feeding and nutrition, and ration evaluation. United States: Thomson Delmar Learning. Retrieved from http://www.delmarlearning.com

University of Namibia. (2011). Neudamm Agricultural College Farm. University of Namibia. Retrieved from http://digital.unam.na/handle/11070.1/4461?show=full

Wyk, B., Wyk, P., \& Wyk, B. (2011). Photo guide to trees of southern Africa. Pretoria, South Africa: Briza Publications.

\section{Copyrights}

Copyright for this article is retained by the author(s), with first publication rights granted to the journal.

This is an open-access article distributed under the terms and conditions of the Creative Commons Attribution license (http://creativecommons.org/licenses/by/3.0/). 